\title{
New Constraints on Precambrian Ocean Composition ${ }^{1}$
}

\author{
John P. Grotzinger and James F. Kasting ${ }^{2}$ \\ Department of Earth, Atmospheric and Planetary Sciences, Massachusetts Institute of Technology, \\ Cambridge, MA 02139
}

\begin{abstract}
A B S T RA C T
The Precambrian record of carbonate and evaporite sedimentation is equivocal. In contrast to most previous interpretations, it is possible that Archean, Paleoproterozoic, and to a lesser extent, Meso to Neoproterozoic seawater favored surplus abiotic carbonate precipitation, as aragonite and (hi-Mg?) calcite, in comparison to younger times. Furthermore, gypsum/anhydrite may have been only rarely precipitated prior to halite precipitation during evaporation prior to about $1.8 \mathrm{Ga}$. Two effects may have contributed to these relationships. First, sulfate concentration of seawater may have been critically low prior to about $1.9 \mathrm{Ga}$ so the product $\mathrm{m}_{\mathrm{Ca}^{+}} \cdot \cdot \mathrm{m}_{\mathrm{SO}_{4}^{-}}$would not have produced gypsum before halite, as in the Mesoproterozoic to modern ocean. Second, the bicarbonate to calcium ratio was sufficiently high so that during progressive evaporation of seawater, calcium would have been exhausted before the gypsum field was reached. The $\mathrm{pH}$ of the Archean and Paleoproterozoic ocean need not have been significantly different from the modern value of 8.1 , even at $\mathrm{CO}_{2}$ partial pressures of a tenth of an atmosphere. Higher $\mathrm{CO}_{2}$ partial pressures require somewhat lower $\mathrm{pH}$ values.
\end{abstract}

\section{Introduction}

It is generally assumed that there have been no significant changes in the composition of seawater during the past 3.5 Gyr (Holland 1972, 1984; Walker 1983). This is based principally on past claims that the sequence of carbonate and evaporite minerals has remained constant. On this basis, limits have been placed on allowable deviations of the concentrations of the major constituents of seawater during the Neoproterozoic (Holland 1984) and, allowing for significantly higher $\mathrm{CO}_{2}$ pressures, the Archean (Walker 1983). However, the model for constant seawater composition recently has been challenged on an observational (Grotzinger 1989) as well as theoretical basis (Kempe and Degens 1985). Here, we discuss the significance of non-uniformitarian carbonate and evaporite mineral precipitation. Previous constraints on the composition of seawater are revised in light of this new evidence that help define likely unidirectional changes in the $\mathrm{CO}_{2}$ pressure of the atmosphere and tectonic regime of the early earth.

\footnotetext{
${ }^{1}$ Manuscript received June 15, 1992; accepted December 1, 1992.

${ }^{2}$ Department of Geosciences, Pennsylvania State University, University Park, PA 16802.
}

\section{Precambrian Carbonates and Evaporites}

The Precambrian sedimentary record to about 3.5 Ga includes dolostones and limestones precipitated originally as aragonite and calcite /Grotzinger 1989; Grotzinger and Read 1983; Hofmann and Jackson 1988; Knoll and Swett 1990). It is subdivisible into several overlapping periods marked by significant variations in the quantity and mode of carbonate precipitation (Grotzinger 1989). Archean carbonate sedimentation featured prolific precipitation of aragonite as giant botryoids up to $1 \mathrm{~m}$ in radius and magnesian calcite as stratigraphic sheets up to several meters thick and extending along strike for over $100 \mathrm{~km}$, in addition to a variety of stromatolite types (figure 1). By comparison, Paleoproterozoic carbonate sedimentation was marked by less spectacular occurrences of massively precipitated aragonite and calcite, although sedimentation by precipitation of cement crusts, particularly in tidal flat settings as microdigitate stromatolites, remained a characteristic mode of platform aggradation (figure 2). In contrast, Mesothrough Neoproterozoic carbonate sedimentation saw the progressive decline in precipitation of massive carbonate cements, although precipitation as cryptocrystalline micritic whitings was typical, particularly in the Neoproterozoic (Knoll and 


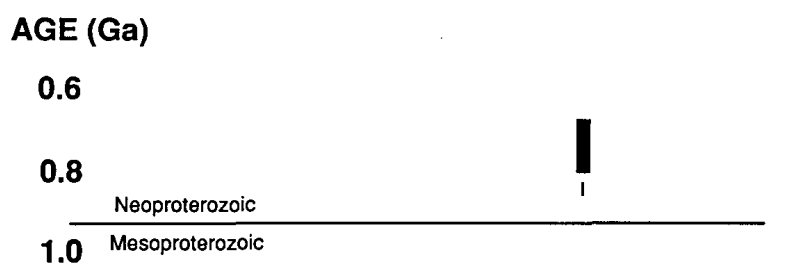

1.2

1.4

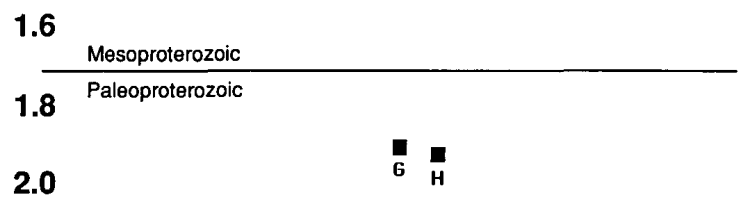

2.2

2.4

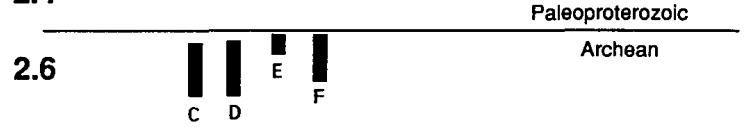

2.8

\section{$3.0 \underset{\mathrm{A}}{\mathrm{B}}$}

Figure 1. Temporal distribution of massive, thick beds of marine cements. This includes botryoidal calcite (formerly aragonite) as well as herringbone calcite (formerly $\mathrm{Mg}$-calcite) that form discrete beds greater than $1 \mathrm{~m}$ thick. The bar length is the error in age of the stratigraphic unit. Note the temporal decrease in the importance of this facies. Each bar represents a different basin; only one bar is tabulated no matter how many beds occur within the basin. If individual beds were tabulated, the high frequency in the Archean would appear even greater. Sources: $A$ (Hofmann et al. 1985); $B$ (Hofmann 1971); $C$ (J. Grotzinger and N. Beukes, unpub. data); $D$ (Martin et al. 1980); E (Sumner et al. 1991); F (Simonson et al. 1993); $G$ (Hofmann and Grotzinger 1985); H (Grotzinger and Friedman 1989); $I$ (Peryt et al. 1990).

Swett 1990). The Neoproterozoic was a transitional interval; certain facies were similar to earlier Proterozoic sequences, but others were akin to Phanerozoic equivalents.

Today, it is significant that despite the 3- to 7fold oversaturation of modern surface seawater with respect to calcium carbonate (Li et al. 1969), precipitation of massive seafloor cements is unknown; all known modern marine cements are restricted to filling pores in reefal buildups or unconsolidated debris. Biological secretion accounts for almost all carbonate precipitation in the modern ocean, despite the fact that the ocean is still significantly oversaturated. Similarly, massive precip-
AGE (Ga)

0.6

0.8

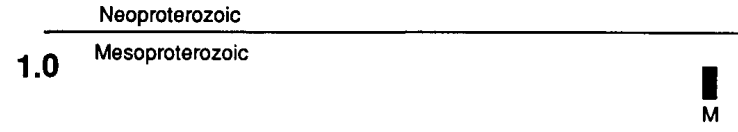

1.2

1.4

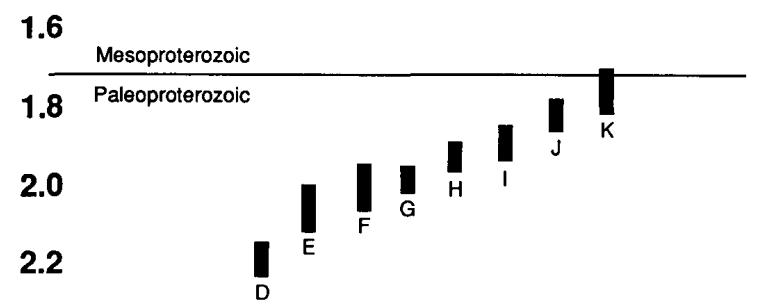

2.4

2.6

Paleoproterozoic

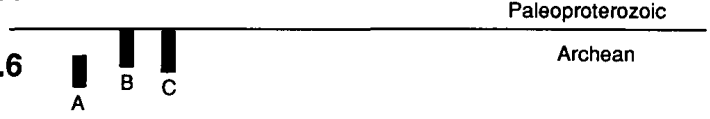

Figure 2. Temporal distribution of microdigitate stromatolites (tidal-flat marine cement crusts). The bar length is the error in age of the stratigraphic unit. Note the temporal decrease in the importance of this facies. Each bar represents a different basin; only one bar is tabulated no matter how many beds occur within the basin. If individual beds were tabulated then the high frequency in the Paleoproterozoic would appear even greater. Sources are provided in figure 15 of Grotzinger (1989).

itation of calcite and aragonite cements directly on the seafloor is only known from rare intervals in the Phanerozoic, such as the Permian /Yurewicz 1977). It seems probable therefore that Precambrian seawater was greatly oversaturated with respect to calcium carbonate and that saturation decreased to Phanerozoic levels throughout the Proterozoic (Grotzinger 1989). This long-term decrease in saturation likely involved numerous shorter-term oscillations when the trend may have been locally reversed. However, data are so sparse that it is not possible to delineate anything other than the billion-year-scale trend.

There is considerable evidence for Precambrian evaporite sedimentation. Evidence for halite is present throughout the record and for the earlier Precambrian, is developed where gypsum is absent. In the late Archean (ca. 2.7 Ga) Fortescue basin, Western Australia, Buick (1992, p. 76) has described "curtailed evaporite paragenesis, from carbonate straight to halite without an intervening 
stage of sulfate precipitation." Because the precipitation sequence differs from Phanerozoic marine evaporites, Buick (1992) interprets it as evidence for lacustrine sedimentation. However, there are no independent "diagnostic" criteria supporting this inference, and a marine origin cannot be discounted. If it is marine, this sequence suggests that the composition of seawater was substantially different at that time. A second example of carbonateto-halite precipitation is found in the $1.90 \mathrm{Ga}$ Rocknest Formation, Northwest Canada. The Rocknest Formation is dominated by restricted tidal-flat facies containing halite casts with no evidence of former gypsum or anhydrite despite sedimentological (Grotzinger 1986) and isotopic (Burdett et al. 1990) evidence for widespread evaporative conditions. A third example of an evaporite sequence that proceeded directly from carbonate to halite occurs in the ca. 1.88 Ga Pethei Group (East Great Slave Lake, Canada). The Pethei Group represents a major, shallow-water carbonate platform and adjacent basin (Hoffman 1974). The uppermost formations, Hearne and Pekanatui, represent the final stages of carbonate precipitation in respectively shallow- and deep-water environments (figure 3). These formations are abruptly overlain by over $100 \mathrm{~m}$ of megabreccia (Stark Formation) interpreted to have formed by evaporite dissolution and collapse (Hoffman et al. 1977). The breccia consists of chaotically dispersed blocks of stromatolitic carbonate up to 50 by $1000 \mathrm{~m}$, dispersed in a brecciated matrix of red mudstone. Hoffman et al. (1977, p. 124) report that "salt crystal casts occur both above and below the megabreccia. The uppermost bedding surface of the Pekanatui Formation, the top of the Pethei Group, is littered with hoppershaped salt casts." The uppermost bed of the Pekanatui Formation is approximately $1 \mathrm{~m}$ of densely packed halite casts with a carbonate matrix. Hoffman et al. (1977, p. 125) conclude that "according to the genetic model we now favor, the end of Pethei carbonate deposition was marked by the precipitation of probably tens of meters of salt." No sulfate evaporite traces occur stratigraphically between the Pethei carbonates and formerly halitebearing lithologies. Consequently, we consider this as compelling evidence in favor of a limited calcium sulfate precipitation from Paleoproterozoic seawater.

A review of reported Precambrian evaporites (Grotzinger 1989) shows that calcium sulfate minerals (or their pseudomorphs) are scarce to absent up to approximately $1.7-1.6 \mathrm{Ga}$, when welldeveloped examples appear (figure 4). Bedded or massive gypsum/anhydrite formed in evaporative

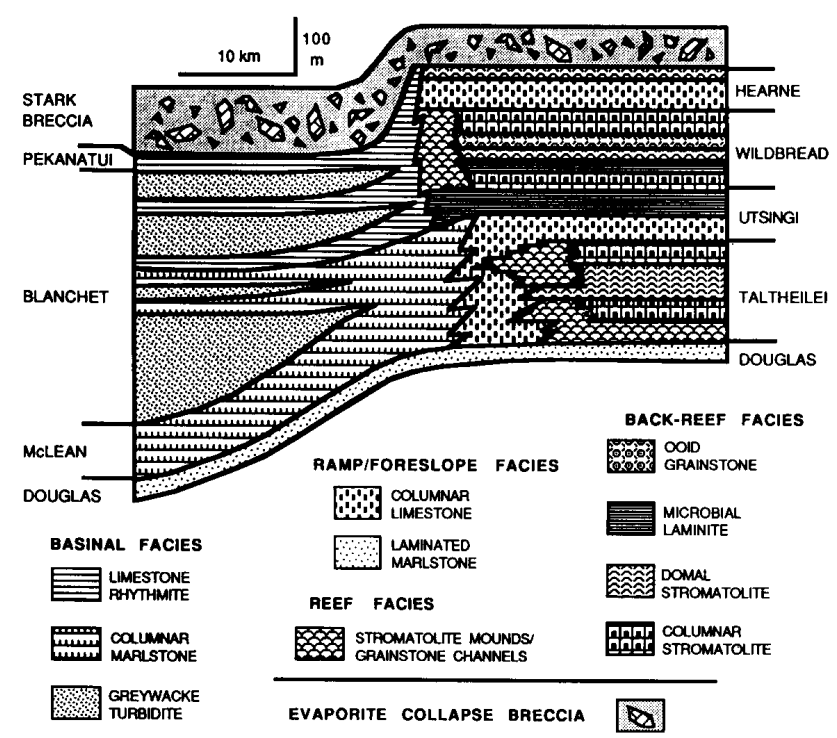

Figure 3. Stratigraphic cross-section of Pethei Group and overlying Stark Formation (megabreccia). Note welldeveloped paleogeographic zonation of carbonate facies, strong platform-to-basin differentiation, and formation of evaporite-collapse breccia over basinal as well as shallow-water carbonate facies. After Hoffman (1974) and Hoffman et al. (1977). The Pethei platform is developed on a spatial scale comparable to the largest Phanerozoic platforms and likely faced a major ocean. It is very difficult to reconcile the passage of carbonate precipitation directly into halite precipitation unless the composition of that ocean was changed relative to younger times. For further elaboration, see text and figure 25.5 in Hoffman et al. (1977).

environments is absent in the Archean and Early Proterozoic record. Such sediments first appear in the Mesoproterozoic (ca. 1.7-1.6 Ga) MacArthur basin, Northern Territory, Australia (Jackson et al. 1987), with others in the approximately 1.2 Ga Borden basin, Baffin Island (Jackson and Ianelli 1981) and approximately 1.2 Ga Amundsen basin, Canadian Arctic Archipelago (Young 1981; Young and Long 1977). In these basins sulfate evaporite deposits are up to tens of meters thick and spread over hundreds of square kilometers. Neoproterozoic (ca. $0.8 \mathrm{Ga}$ ) sulfate evaporites occur in the Amadeus basin, central Australia, where they are distributed over $>100,000 \mathrm{~km}^{2}$ and have an average thickness of about $800 \mathrm{~m}$, including halite (Lindsay 1987).

In the past, the hypothesis that Precambrian seawater was similar to older Phanerozoic and modern seawater (e.g., Buick and Dunlop 1990; Walker 1983) was based on references to the rock record purported to contain preserved mineral assem- 


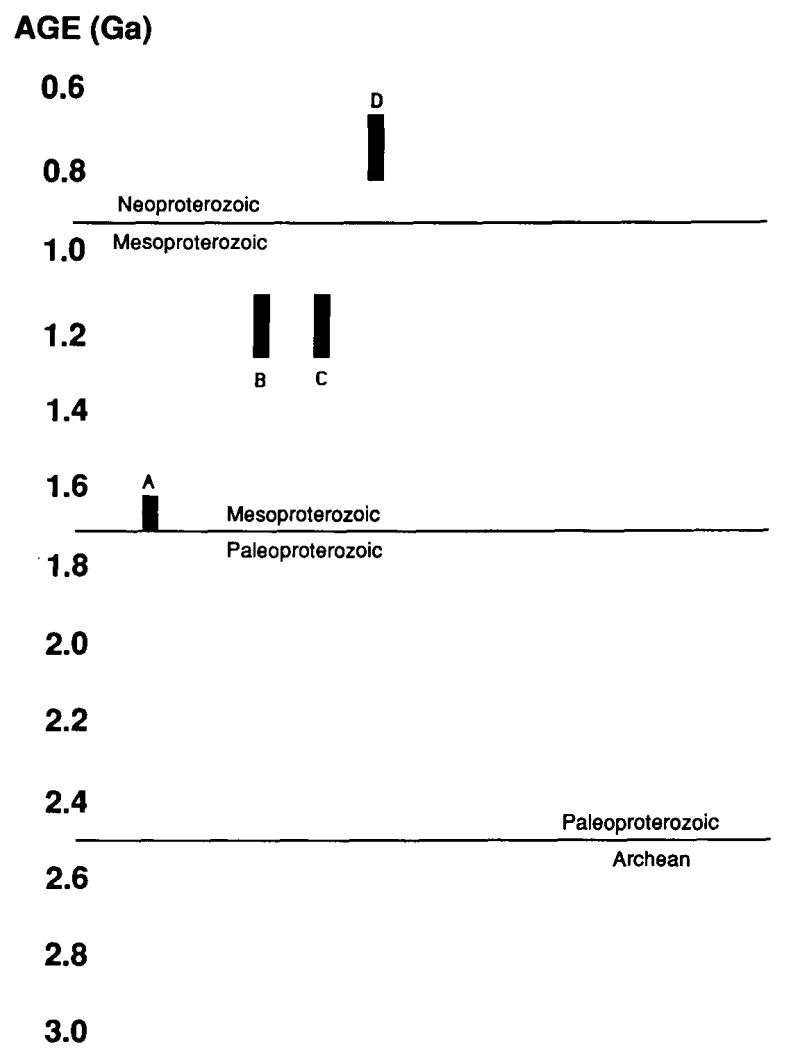

Figure 4. Temporal distribution of massive sulfate evaporites. The bar length is the error in age of the stratigraphic unit. Note the absence of massive sulfate deposits prior to about 1.7 Ga. Sources: $A$ (Jackson et al., 1987); $B$ (Young 1981; Young and Long 1977); $C$ (Jackson and Ianelli 1981); $D$ (Lindsay 1987).

blages or pseudomorphs of former evaporite assemblages. In most cases, however, the stratigraphy and sedimentology of the deposit are poorly understood, and the precipitation sequence has not been firmly established, particularly for the Archean and Paleoproterozoic. Most troublesome is that reports of "evaporite" pseudomorphs, most notably gypsum, are often unsubstantiated by reliable criteria. For example, gypsum pseudomorphs of the Rum Jungle, northern Australia (Crick and Muir 1980) have been shown to be a high-temperature discoidal form of magnesite (Bone 1983). Similarly, calcitized "gypsum" fans of the Late Archean Cheshire Formation, Rhodesia, (Martin, et al. 1980) are most likely calcitized aragonite botryoids (Grotzinger 1989). Furthermore, the context in which documented pseudomorphs occur is seldom discussed in terms of paleoenvironment and the extent to which the mineralogy may have been influenced by influx of non-marine waters (Hardie 1984). In the rare instance where it has been possible to document convincingly the former presence of primary, probably evaporative gypsum (now pre- served as barite [Buick and Dunlop 1990]), there likely was a considerable influence on the local composition of seawater through influx of landderived calcium-rich waters from erosion of highly basaltic surrounding source areas. The hydrologic restriction required to precipitate evaporites must leave a strong non-marine signature on both the geochemistry and the sedimentology of the deposit (Hardie 1984). Consequently, evaporite deposits interlayered with marine sediments may not necessarily yield the correct sequence of evaporite minerals predicted by precipitation from normal seawater; minerals such as gypsum could owe more to brines of continental origin than marine origin.

Perhaps the greatest hindrance to the successful interpretation of the Precambrian evaporite record is its treatment as one time interval, by grouping observations from temporally distinct geologic periods. This practice results in the use of true gypsum deposits of Neoproterozoic age to constrain the composition of seawater at $3.5 \mathrm{Ga}$ (Holland 1984; Walker 1983), and any long-term trends in the history of evaporites are masked. By temporally subdividing the Precambrian record of evaporite sedimentation, as with the carbonate record discussed above, significant potential variations in the precipitation sequence of marine evaporites are revealed.

Significantly, the first appearance of abundant sulfate evaporites coincides with the demise of common, massively precipitated seafloor carbonate cements at ca. 1.7 to $1.6 \mathrm{Ga}$, approximately coincident with the Paleoproterozoic/Mesoproterozoic boundary (figures 1 and 2). A model (Grotzinger 1989| to account for this coincidence proposes that Archean, Paleoproterozoic, and to a lesser extent, Meso- to Neoproterozoic seawater favored surplus abiotic carbonate precipitation, as aragonite and (hi-Mg?) calcite, in comparison to younger times. Seawater then was possibly highly oversaturated, and any perturbation such as microbially induced uptake of $\mathrm{CO}_{2}$ might have caused immediate and prolific precipitation of calcium carbonate. The ratio of $\left[\mathrm{HCO}_{3}^{-}\right]$to $\left[\mathrm{Ca}^{2+}\right]$ may also have been increased, relative to Phanerozoic seawater, so that $2\left[\mathrm{HCO}_{3}^{-}\right]$was close to or even greater than $\left[\mathrm{Ca}^{2+}\right]$. Seawater might have precipitated abundant abiotic carbonate, adding to that induced by microbial processes, and perhaps inducing carbonate production to expand to tidal flats where tufas could form. In the process, most or all available calcium would be extracted simply by precipitation of carbonate and, during an evaporative situation, little or no calcium sulfate would have precipitated except near sites of continental runoff 
(e.g., deltas) where influx of additional calcium might be expected. This condition would have been maintained until about $1.8-1.6 \mathrm{Ga}$, when the $\left[\mathrm{HCO}_{3}^{-}\right] /\left[\mathrm{Ca}^{2+}\right]$ ratio would have changed so that $2\left[\mathrm{HCO}_{3}^{-}\right]$was less than $\left[\mathrm{Ca}^{2+}\right]$ (Grotzinger 1989).

\section{Precambrian Seawater}

Walker (1983) used the method of Holland (1972) that brackets likely ranges in seawater compositions through geologic time based on constraints imposed by assemblages of preserved and inferred evaporite minerals in the stratigraphic record. The relative abundance of minerals in marine evaporites is used to set limits on excursions in the composition of seawater. The new interpretation of the sedimentary record permits significant revisions to previous interpretations of the composition of Precambrian seawater, particularly with regard to the decay of Archean conditions throughout the Proterozoic.

Acceptance of the supposition that gypsum was not part of the normal marine evaporite sequence during the Archean and Paleoproterozoic leads to one of the following two conclusions: Either, (1) oceanic sulfate concentrations were vanishingly low during this time, or (2) calcium was removed entirely by formation of calcium carbonate during progressive evaporation of seawater.

$$
\mathrm{Ca}^{++}+2 \mathrm{HCO}_{3}^{-} \rightarrow \mathrm{CaCO}_{3}+\mathrm{CO}_{2}+\mathrm{H}_{2} \mathrm{O}
$$

Sulfate Concentration. The factors controlling Archean sulfate concentrations have been discussed by Walker (1983) and Walker and Brimblecombe (1985). They argue that sulfate concentrations of $<10^{-3}$ moles/liter $(1 / 30$ th of the present value) are unlikely because sulfate would have been formed by oxidation of volcanic $\mathrm{SO}_{2}$ and $\mathrm{H}_{2} \mathrm{~S}$, even in the absence of atmospheric $\mathrm{O}_{2}$. Photochemical modeling (Kasting 1990; Kasting, et al. 1983 indicates that, in an anoxic atmosphere, only about $15 \%$ of volcanically emitted $\mathrm{SO}_{2}$ would actually have been converted to sulfate; most of the $\mathrm{SO}_{2}$ should have been dissolved in the ocean, yielding bisulfite and sulfite. The fate of these compounds in solution is uncertain, but it is likely that a significant fraction of the sulfur would have ended up as sulfate through disproportionation

$$
4 \mathrm{SO}_{3}^{-2} \rightarrow 3 \mathrm{SO}_{4}^{-2}+\mathrm{S}
$$

Hence, Walker (1983) and Walker and Brimblecombe (1985) are probably correct in assuming a non-negligible sulfate concentration in the Ar- chean ocean, on the order of $1 \mathrm{mmole} / \mathrm{l}$. However, Holland (1993) suggests that an abrupt rise in oxygen to $15 \%$ PAL occurred at about 2.1-1.9 Ga. This conclusion is reinforced by the observation that a major change in sulfur isotopes occurs at $\sim 2.2 \mathrm{Ga}$, a change thought by some to indicate a rise in oceanic sulfate concentrations (Cameron 1982; Lambert and Donnelly 1986). Consequently, it is likely that after $\sim 2.2 \mathrm{Ga}$ all sulfur-bearing compounds (e.g., pyrite) would have been oxidized and that sulfate concentrations in oceans were close to present values.

Given the composition of modern seawater, saturation with respect to gypsum and halite is reached simultaneously for a saturation factor of about 11 (Holland, 1984). At this point the product $\mathrm{m}_{\mathrm{Ca}^{++}}{ }^{+} \cdot \mathrm{m}_{\mathrm{SO}^{-}}{ }^{-}$equals about $23(\mathrm{mmole} / \mathrm{l})^{2}$ the approximate minimum value for the appearance of gypsum before halite. This minimum value may not have been attained until after about 1.9 Ga due to low sulfate concentrations. Prior to about 1.9 $\mathrm{Ga}$, we estimate that $\left[\mathrm{Ca}^{++}\right]$and $\left[\mathrm{SO}_{4}^{-}\right]$were on the order of $10 \mathrm{mmole} / 1$ (see below) and $1 \mathrm{mmole}$ / 1 , respectively. Consequently, their product would have been less than the minimum value to precipitate gypsum before halite by about a factor of two. Thus, we cannot discount the possibility that low sulfate concentrations were, at least in part, responsible for the rarity or absence of Archean and Paleoproterozoic gypsum.

Bicarbonate Concentration. Another explanation for the dearth of Paleoproterozoic and Archean gypsum is that calcium was depleted by the formation of calcium carbonate during progressive evaporative concentration of marine brines. Reaction (1) reveals that this will occur when the bicarbonate ion concentration exceeds twice the calcium ion concentration

$$
\left[\mathrm{HCO}_{3}^{-}\right]>2\left[\mathrm{Ca}^{+2}\right]
$$

This possibility has already been explored by Kempe and Degens (1985). They suggest that the Archean ocean was a "soda ocean" in which bicarbonate was the dominant anion, even exceeding chloride. Such an ocean would provide an obvious explanation for the widespread deposition of marine aragonite and calcite. Kempe and Degens (1985) also suggest that the soda ocean may have persisted until as late as $800 \mathrm{Ma}$, that it had a pH comparable to modern soda lakes (between 9 and 11 ), and that it would have reduced the atmospheric $\mathrm{CO}_{2}$ partial pressure to relatively low values within a few million years after the earth's formation. However, as discussed above and in Grotzinger (1989), the geological record indicates 
that the transition from a bicarbonate-rich ocean to a more modern ocean occurred between approximately 1.8 and $1.6 \mathrm{Ga}$, and not at $0.8 \mathrm{Ga}$. Furthermore, we argue below that $\mathrm{pCO}_{2}$ must have been high during the Archean, so the ocean $\mathrm{pH}$ must have been lower than Kempe and Degens (1985) proposed. Despite this, we agree that a bicarbonate-rich ocean is consistent with rapid terrestrial degassing (Fanale 1971; Holland 1984; Walker 1985) and with the fact the carbon is geochemically much more abundant than chlorine.

One can examine the absence of Paleoproterozoic and Archean gypsum in more detail by using a simple equilibrium model of the carbonate system (Holland 1972; Walker 1983). Following Walker (1983), we assume a uniform ocean temperature of $25^{\circ} \mathrm{C}$ and ignore any variation in dissolved carbon concentration and $\mathrm{pH}$ between the surface and deep ocean. Equilibrium constants for the carbonate system are from Broecker and Peng (1982). Like Walker, we assume that the Paleoproterozoic and Archean ocean was supersaturated with respect to calcite by about a factor of two

$$
\left[\mathrm{Ca}^{2+}\right]\left[\mathrm{CO}_{3}^{-2}\right]=10^{-6} \mathrm{moles}^{2} / 1^{2}
$$

Given these assumptions, the carbonate system can be completely specified by fixing any two parameters. For present purposes, we use the atmospheric $\mathrm{CO}_{2}$ partial pressure and oceanic $\mathrm{pH}$.

To make any use of this model we need to incorporate additional information regarding the composition of the Archean atmosphere and ocean. Equation (3) above defines one constraint on the system. The total amount of available carbon is another. The present crustal inventory of carbon is approximately $10^{23} \mathrm{~g}$ (Holland 1978; Ronov and Yaroshevskiy 1967; Walker 1985). Most of this carbon is stored in carbonate rocks. The amount of carbon dissolved in the oceans is much smaller, $\sim 4 \times 10^{19} \mathrm{~g}$ (Broecker and Peng 1982), and the atmospheric inventory, $7 \times 10^{17} \mathrm{~g}$, is smaller still. The distribution of carbon may have been considerably different during the Archean if the continents were much smaller, so that there were fewer stable platforms on which to store carbonate rock (Walker 1985). Walker suggests that as much as one-seventh of the total crustal carbon inventory, or $\sim 10^{22} \mathrm{~g} \mathrm{C}$, may have been present in the atmosphere-ocean system on a completely oceancovered earth. We take this as a reasonable upper bound on the amount of carbon available during the Archean.

A third constraint can be added on the basis of climatic considerations. According to stellar evolu- tion models (Gough 1981; Newman and Rood 1977), solar luminosity increased from about $70 \%$ of its present value 4.6 b.y. ago to $82 \%$ of its present value by the end of the Archean eon. To keep the oceans from freezing solid, the lower solar flux must have been offset by either an increase in the earth's greenhouse effect or by a decrease in its albedo (Sagan and Mullen 1972). The albedo could have been lower if cloud cover was reduced (Henderson-Sellers 1979; Rossow et al. 1982); however, this explanation is unlikely if the Archean climate was actually warmer than today, as implied by the lack of evidence of glaciation prior to about $2.5 \mathrm{Ga}$ (Crowley 1983; Frakes 1979). Enhanced concentrations of atmospheric greenhouse gases could have kept the climate warm; the most probable candidates are carbon dioxide and methane (Kasting 1987; Kiehl and Dickinson 1987; Owen et al. 1979; Walker et al. 1981). Ammonia is also a good greenhouse gas but its concentration was probably kept low by rapid photolysis (Kasting 1982; Kuhn and Atreya 1979). If the methane concentration was $100 \mathrm{ppm}$ or below, as seems likely (Kasting et al. 1983; Zahnle 1986), carbon dioxide would have been the dominant greenhouse gas. Its partial pressure during the Huronian glaciation (ca. 2.3 Ga) should have been between 0.03 and $0.3 \mathrm{~atm}$ to produce a "glacial" mean surface temperature of $5^{\circ}$ to $20^{\circ} \mathrm{C}$ (Kasting 1987). Somewhat higher $\mathrm{CO}_{2}$ concentrations would be needed to produce a warm Archean surface. We therefore take $0.03 \mathrm{~atm}$ as a reasonable lower limit on the Archean $\mathrm{CO}_{2}$ partial pressure. Note that if $\mathrm{pCO}_{2}$ were much lower than $0.03 \mathrm{~atm}$, as Kempe and Degens suggest, the oceans should have frozen and volcanically released $\mathrm{CO}_{2}$ would have accumulated in the atmosphere until liquid water reappeared and silicate weathering recommenced (Kasting 1987; Walker et al. 1981).

These three constraints can be used to estimate limits on the composition and $\mathrm{pH}$ of the Archean ocean (figure 5). The slanted line running from the lower left to the upper right of the diagram is the locus of points where the bicarbonate concentration is exactly twice the calcium ion concentration. The shaded portion of the diagram to the lower right of this line is excluded by the absence of gypsum from the Archean evaporite record. The curved line is the locus of points where the combined carbon content of the atmosphere plus ocean is $10^{22} \mathrm{~g}$. (We have here assumed that the volume of the Archean ocean was the same as today.) The shaded region above this curve is excluded on the basis of available carbon. The horizontal line at $\mathrm{pCO}_{2}=0.03$ atm is the lower limit on $\mathrm{CO}_{2}$ derived from climate modeling. Taken together, the three 


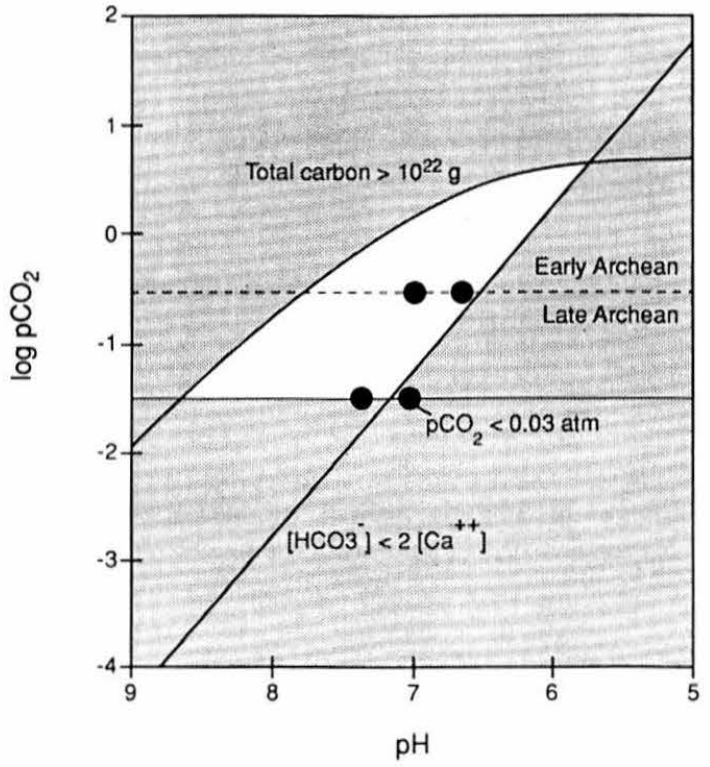

Figure 5. Relationship between partial pressure of carbon dioxide and concentration of $\mathrm{H}^{+}$ions in seawater. Possible composition of Archean to Paleoproterozoic seawater shown in white. Black dots represent bounds on excursions in $\mathrm{pH}$ for fixed values of $\mathrm{pCO}_{2}$ at 0.3 and $0.03 \mathrm{~atm}$.

curves define a roughly triangular-shaped region that represents the most likely combinations of atmospheric $\mathrm{CO}_{2}$ partial pressure and oceanic $\mathrm{pH}$ during the Archean and Paleoproterozoic. Allowable $\mathrm{pH}$ values range from about 5.7 to 8.6 , with lower $\mathrm{pH}$ values favored at higher $\mathrm{CO}_{2}$ partial pressures. Allowable $\mathrm{CO}_{2}$ partial pressures range from $0.03 \mathrm{~atm}$ to about $5 \mathrm{~atm}$. By the beginning of Paleoproterozoic time, when the climate is known to have been cool, the upper limit on $\mathrm{pCO}_{2}$ can be reduced to about $0.3 \mathrm{~atm}$ (dashed line). The corresponding lower limit on oceanic $\mathrm{pH}$ at that time is approximately 6.5 .

An independent method of estimating ocean $\mathrm{pH}$ during the Late Archean is to use Holland's figure for the dissolved $\mathrm{Fe}^{++}$concentration to explain the banded iron formations, $\geq 1.0 \mathrm{ppm}$ by weight (Holland 1984, p. 397), and to assume that the ocean was approximately saturated with respect to siderite as well as calcite. This assumption is justified by the appearance of siderite associated with limestone facies. Following Holland, we assume that dissolved $\mathrm{Fe}^{++}$has a similar activity coefficient to $\mathrm{Ca}^{++}$and that neither is significantly complexed at typical ocean pHs. In this case, the $\mathrm{Fe}^{++} / \mathrm{Ca}^{++}$ ratio in late Archean seawater is simply equal to the ratio of the solubility products of siderite and calcite, $\sim 6 \times 10^{-3}$ (Holland 1984). For $\left[\mathrm{Fe}^{++}\right]=$ 1-3 ppm by weight, the corresponding values of
$\left[\mathrm{Ca}^{++}\right]$are 3-9 mmoles/l (compared to 10.3 mmoles/l today). With $\left[\mathrm{CO}_{3}^{--}\right]$fixed by equation (4), ocean $\mathrm{pH}$ can be determined from the relation

$$
\left[\mathrm{H}^{+}\right]=\sqrt{\frac{\alpha \mathrm{K}_{1} \mathrm{~K}_{2} \mathrm{pCO}_{2}}{[\mathrm{CO}]_{3}^{-}}}
$$

where $\alpha, \mathrm{K}_{1}$, and $\mathrm{K}_{2}$ are, respectively, the Henry's Law coefficient for $\mathrm{CO}_{2}$ and the first and second dissociation constants for carbonic acid. Using values at $25^{\circ} \mathrm{C}$ gives: $\mathrm{pH}=7.1$ to 7.4 for $\mathrm{pCO}_{2}=0.03$ atm; $\mathrm{pH}=6.6$ to 6.9 for $\mathrm{pCO}_{2}=0.3$ atm.

These $\mathrm{pH}$ values fall for the most part within the unshaded portion of figure 5, left of the line where $\left[\mathrm{HCO}_{3}^{--}\right]=2\left[\mathrm{Ca}^{++}\right]$. Consequently, this calculation is consistent with the analysis presented earlier in which bicarbonate is assumed to exhaust calcium during the formation of evaporites, although we note that the calculated values fall close enough to the boundary to warrant caution in interpretation. This argument is aided, however, by the likelihood that the $\mathrm{Fe}^{++}$concentration in surface seawater was probably lower than $1 \mathrm{ppm}$ because iron was being precipitated as oxides as well as siderite; thus, both the $\left.\mid \mathrm{CO}_{3}^{--}\right]$ and the $\mathrm{pH}$ of the surface ocean should have been higher than calculated here. Such an ocean barely qualifies as a "soda ocean": for $\mathrm{pCO}_{2}=0.3 \mathrm{~atm}$ and $\mathrm{pH}=6.9$, the bicarbonate concentration is $\sim 70 \mathrm{mmoles} / \mathrm{l}$. This value may be compared with present day $\mathrm{HCO}_{3}^{-}$and $\mathrm{Cl}^{-}$concentrations of 2 and $546 \mathrm{mmoles} / \mathrm{l}$, respectively. Evidently, bicarbonate made a much larger contribution to oceanic charge balance than it does now, but it was unlikely to have been the dominant anion in seawater during late Archean or younger times. To the extent that banded iron formation may have been less abundant during the earlier Archean, $\left[\mathrm{Fe}^{++}\right]$could have been lower, and oceanic $\mathrm{pH}$ and $\left[\mathrm{HCO}_{3}^{-}\right]$higher, than the values found here.

\section{Summary}

Our reinterpretation of the carbonate-evaporite record significantly narrows the range of possible compositions for the Archean and Paleoproterozoic ocean. Two mechanisms may account for the paucity of gypsum evaporites prior to about $1.7 \mathrm{Ga}$. First, sulfate concentration of seawater may have been critically low prior to about $1.9 \mathrm{Ga}$ so that gypsum would not form before halite as in the modern ocean. Second, the bicarbonate to calcium ratio was sufficiently high that during the progressive evaporation of seawater, calcium would have 
been exhausted before the gypsum field was reached. We find that the $\mathrm{pH}$ of the Archean and Paleoproterozoic ocean need not have been significantly different from the modern value of 8.1 , even at $\mathrm{CO}_{2}$ partial pressures of a tenth of an atmosphere. Higher $\mathrm{CO}_{2}$ partial pressures require somewhat lower $\mathrm{pH}$ values, but not as low as those estimated by Walker (Walker 1983; Walker 1985). Higher ocean pHs make intuitive sense for reasons outlined by Kempe and Degens (1985): An ocean that was too acidic would not remain so for long because it would dissolve silicate minerals on the seafloor, replacing $\mathrm{H}^{+}$ions with $\mathrm{Na}^{+}, \mathrm{K}^{+}, \mathrm{Ca}^{2+}$, and $\mathrm{Mg}^{2+}$ ions until its $\mathrm{pH}$ became more neutral. To actually predict the correct oceanic $\mathrm{pH}$ would require a sophisticated geochemical cycle model along with information regarding continental weathering rates and the intensity of basaltseawater interactions in hydrothermal circulation systems along the midocean ridges. Since such information is hard to come by, it may be difficult to go beyond the simple constraints outlined in figure 5 .

\section{A CKNOWLEDGMENTS}

This manuscript has benefited from discussions with $\mathrm{H}$. Holland and D. Sumner. The research was supported by NSF Grant EAR-9058199 to JPG. We thank $B$. Wilkinson and an anonymous reader for careful review of the manuscript and useful comments.

\section{REFERENCES CITED}

Bone, Y., 1983, Interpretation of magnesites at Rum Jungle, N.T., using fluid inclusions: Jour. Geol. Soc. Australia, v. 30, p. 375-381.

Broecker, W. S., and Peng, T. H., 1982, Tracers in the Sea: Palisades, NY, Lamont-Doherty Geol. Obs., $690 \mathrm{p}$.

Buick, R., 1992, The antiquity of oxygenic photosynthesis: evidence from stromatolites in sulphate-deficient Archean lakes: Science, v. 235, p. 74-77.

_-, and Dunlop, J. S. R., 1990, Evaporitic sediments of early Archean age from the Warrawoona Group, North Pole, Western Australia: Sedimentology, v. 37, p. 247-278.

Burdett, J. W.; Grotzinger, J. P.; and Arthur, M. A., 1990, Did major changes in the stable-isotope composition of Proterozoic seawater occur?: Geology, v. 18, p. 227-230.

Cameron, E. M., 1982, Sulphate and sulphate reduction in early Precambrian oceans: Nature, v. 296, p. 145-148.

Crick, I. H., and Muir, M. D., 1980, Evaporites and uranium mineralisation in the Pine Creek Geosyncline, in Ferguson, J., and Goleby, A. B., eds., Uranium in the Pine Creek Geosyncline: Int. Atomic Energy Agency, p. 531-542.

Crowley, T. J., 1983, The geologic record of climate change: Rev. Geophys. Space Phys., v. 21, p. 828-877.

Fanale, F. P., 1971, A case for catastrophic early degassing of the earth: Chem. Geol., v. 8, p. 71-105.

Frakes, L. A., 1979, Climates throughout Geologic Time: Amsterdam, Elsevier, 310 p.

Gough, D. O., 1981, Solar interior structure and luminosity variations: Solar Physics, v. 74, p. p. 21-34.

Grotzinger, I. P., 1986, Cyclicity and paleoenvironmental dynamics, Rocknest platform, northwest Canada: Geol. Soc. America Bull., v. 97, p. 1208-1231.

, 1989, Facies and evolution of Precambrian carbonate depositional systems: emergence of the mod- ern platform archetype, in Crevello, P. D.; Wilson, J. L.; et al., eds., Controls on Carbonate Platform and Basin Development: Soc. Econ. Paleont. Mineral. p. 79-106.

- - and Friedman, J. S., 1989, Occurrence of thick crusts of former botryoidal aragonite, Rifle and Beechey Formations (1.97 Ga), Kilohigok Basin, NWT: Geol. Assoc. Canada Prog. with Abs., v. 14, p. A77.

—_- , and Read, J. F., 1983, Evidence for primary aragonite precipitation, lower Proterozoic (1.9 Ga) dolomite, Wopmay orogen, northwest Canada: Geology, v. 11, p. $710-713$.

Hardie, L. A., 1984, Evaporites: marine or non-marine?: Am. Jour. Sci., v. 284, p. 193-240.

Henderson-Sellers, A., 1979, Clouds and the long term stability of the earth's atmosphere and climate: Nature, v. 279, p. 786-788.

Hoffman, P. F., 1974, Shallow and deep-water stromatolites in lower Proterozoic platform-to-basin facies change, Great Slave Lake, Canada: Am. Assoc. Petrol. Geol. Bull., v. 58, p. 856-867.

; Bell, I. R.; Hildebrand, R. S.; and Thorstad, L., 1977, Geology of the Athapuscow Aulocogen, East Arm of Great Slave Lake, District of Mackenzie, in Current research, part A: Geol. Survey Canada Paper 84-1 A, p. 117-146.

Hofmann, H. J., 1971, Precambrian fossils, pseudofossils, and problematica in Canada: Geol. Survey Canada Bull., v. 189, p. 1-146.

- , and Grotzinger, J. P., 1985, Shelf-facies microbiotas from the Odjick and Rocknest formations (Epworth Group; $1.89 \mathrm{Ga})$, northwestern Canada: Can. Jour. Earth Sci., v. 22, p. 1781-1792.

- , and Jackson, G. D., 1988, Proterozoic ministromatolites with radial-fibrous fabric: Sedimentology, v. 34, p. 963-971.

- ; Thurston, P. C.; and Wallace, H., 1985, Archean stromatolites from Uchi greenstone belt, northwest- 
ern Ontario, in Ayres, L. D.; Thurston, P. C.; et al., (eds., Evolution of Archean supracrustal sequences: Geol. Assoc. Canada, p. 125-132.

Holland, H. D., 1972, The geologic history of sea wateran attempt to solve the problem: Geochim. Cosmochim. Acta, v. 36, p. 637-651.

- 1978, The Chemistry of the Atmospheres and Oceans: New York, Wiley, $351 \mathrm{p}$.

- 1984, The Chemical Evolution of the Atmosphere and Oceans: Princeton, Princeton University Press, $582 \mathrm{p}$.

Jackson, G. D., and Ianelli, T. R., 1981, Rift-related cyclic sedimentation in the Neohelikian Borden Basin, northern Baffin Island, in Campbell, F. H. A., ed., Proterozoic Basins of Canada: Geol. Survey Canada Paper 81-10, p. 269-302.

Jackson, M. J.; Muir, M. D.; and Plumb, K. A., 1987, Geology of the southern McArthur Basin, Northern Territory: Australia Bur. Mineral Res., Geology Geophys., 173 p.

Kasting, J. F., 1982, Stability of ammonia in the primitive terrestrial atmosphere: Jour. Geophys. Res., v. 87, p. 3091-3098.

-1987, Theoretical constraints on oxygen and carbon dioxide concentrations in the Precambrian atmosphere: Precamb. Res., v. 34, p. 205-229.

-1990 , Bolide impacts and the oxidation state of carbon in the earth's early atmosphere: Origins of Life, v. 20, p. 199-231.

__ Zahnle, K. J.; and Walker, J. C. G., 1983, Photochemistry of methane in the earth's early atmosphere: Precamb. Res., v. 20, p. 121-148.

Kempe, S., and Degens, E. T., 1985, An early soda ocean?: Chem. Geology, v. 53, p. 95-108.

Kiehl, J. T., and Dickinson, R. E., 1987, A study of the radiative effects of enhanced atmospheric $\mathrm{CO}_{2}$ and $\mathrm{CH}_{4}$ on early earth surface temperatures: Jour. Geophys. Res., v. 92, p. 2991-2998.

Knoll, A. H., and Swett, K., 1990, Carbonate deposition during the later Proterozoic Era: an example from Spitsbergen: Am. Jour. Sci., v. 290A, p. 104-132.

Kuhn, W. R., and Atreya, S. K., 1979, Ammonia photolysis and the greenhouse effect in the primordial atmosphere of the earth: Icarus, v. 37, p. 207-213.

Lambert, I. B., and Donnelly, T. H., 1986, The paleoenvironmental significance of trends in sulfur isotope compositions in the Precambrian: a critical review, in Herbert, H. K., ed., Stable Isotopes and Fluid Processes in Mineralisation: Geol. Soc. Australia Spec. Pub., p. 260-268.

Li, T. H.; Takahashi, T.; and Broecker, W. S., 1969, The degree of saturation of $\mathrm{CaCO}_{3}$ in the oceans: Jour. Geophys. Res., v. 74, p. 5507-5525.

Lindsay, J. F., 1987, Upper Proterozoic evaporites in the Amadeus basin, central Australia, and their role in basin tectonics: Geol. Soc. America Bull., v. 99, p. 852-865.

Martin, A.; Nisbet, E. G.; and Bickle, M. J., 1980, Archean stromatolites of the Belingwe Greenstone Belt, Zimbabwe (Rhodesia): Precamb. Res., v. 13, p. 337-362.
Newman, M.J., and Rood, R. T., 1977, Implications of solar evolution for the earth's early atmosphere: Science, v. 198, p. 1035-1037.

Owen, T.; Cess, R. D.; and Ramanathan, V., 1979, Early earth: an enhanced carbon dioxide greenhouse to compensate for reduced solar luminosity: Nature, v. 277 , p. 640-642.

Peryt, T. M.; Hoppe, A.; Bechstadt, T.; Koster, J.; Pierre, C.; and Richter, D. K., 1990, Late Proterozoic aragonite cement crusts, Bambui Group, Minas Gerais, Brazil: Sedimentology, v. 37, p. 279-286.

Ronov, A. B., and Yaroshevskiy, A. A., 1967, Chemical structure of the earth's crust: Geochemistry, v. 11, p. 1041-1066.

Rossow, W. B.; Henderson-Sellers, A.; and Weinrich, S. K., 1982, Cloud feedback: a stabilizing effect for the early earth?: Science, v. 217, p. 1245-1247.

Sagan, X. X., and Mullen, X. X., 1972, Earth and Mars: evolution of atmospheric and surface temperature: Science, v. 177, p. 52.

Simonson, B. M.; Schubel, K. A.; and Hassler, S. W., 1993, Carbonate sedimentology of the early Precambrian Hamersley Group of Western Australia, in Geol. Soc. Western Australia, in press.

Sumner, D. Y.; Beukes, N. J.; and Grotzinger, J. P., 1991, Massive marine cementation of the Archean Campbellrand-Malmani carbonate platform: Geol. Assoc. Canada Prog. with Abs., v. 16, p. A120.

Walker, J. C. G., 1983, Possible limits on the composition of the Archean ocean: Nature, v. 302, p. $518_{-}^{-}$ 520.

- 1985, Carbon dioxide on the early earth: Origins of Life, v. 16, p. 117-127.

, and Brimblecombe, P., 1985, Iron and sulfur in the pre-biologic ocean: Precamb. Res., v. 28, p. 205-222.

—, Hays, P. B.; and Kasting, J. F., 1981, A negative feedback mechanism for the long-term stabilization of earth's surface temperature: Jour. Geophys. Res., v. 86, p. $9776-9782$.

Young, G. M., 1981, The Amundsen embayment, Northwest Territories: relevance to the upper Proterozoic evolution of North America, in Campbell, F. H. A., ed., Proterozoic basins of Canada: Geol. Survey Canada, p. 203-218.

, and Long, D. G. F., 1977, Carbonate sedimentation in a late Precambrian shelf sea, Victoria Island, Canadian Arctic Archipelago: Jour. Sed. Pet., v. 47, p. 943-955.

Yurewicz, D. A., 1977, Origin of the massive Capitan Limestone (Permian), Guadalupe Mountains, New Mexico and West Texas, in Upper Guadalupian Facies, Permian Reef Complex, Guadalupe Mountains, New Mexico and West Texas, in Field Conference Guidebook: Soc. Econ. Paleont. Mineral. Permian Basin Sect., p. 45-92.

Zahnle, K. J., 1986, Photochemistry of methane and the formation of hydrocyanic acid (HCN) in the earth's early atmosphere: Jour. Geophys. Res., v. 91, p. 2819-2834. 